\title{
Contamination of water, soil and plant with arsenic and heavy metals
}

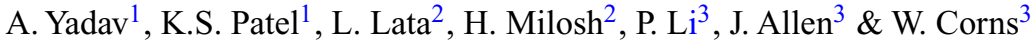 \\ ${ }^{1}$ School of Studies in Chemistry/Environmental Science, Pt. Ravishankar Shukla University, Raipur, India \\ ${ }^{2}$ Department of Soil Science/Geology, Maria Curie-Skłodowska University, Lublin, Poland \\ ${ }^{3}$ PS Analytical Ltd, Arthur House, Orpington, Kent, UK
}

\begin{abstract}
The environment of Ambagarh Chowki, Rajnandgaon, central India is contaminated with As at excessive levels. The domestic animals are suffering with the diseases due to intake of the contaminated water and food. In this work, the contamination of the water, soil and plant leaf with As and other heavy metals (HMs) i.e. $\mathrm{Cr}, \mathrm{Mn}, \mathrm{Cu}, \mathrm{Zn}$ and $\mathrm{Pb}$ in the village Koudikasa are described. The concentration of $\mathrm{As}$ in the 45 dried leaves were ranged from $0.3-27 \mathrm{mg} \mathrm{kg}^{-1}$ with mean value $(\mathrm{p}=0.05)$ of $5.6 \pm 1.4 \mathrm{mg} \mathrm{kg}^{-1}$. The toxic inorganic arsenic species are found to be dominated. The bioindicators for the arsenic and other HMs contaminations are highlighted.
\end{abstract}

\section{INTRODUCTION}

Arsenic, a carcinogenic environmental and occupational pollutant is a menace to all of us due to human poison (Hong et al., 2014). The contamination of the environments with As and other heavy metals (HMs) in the several regions of the World were reported (Bhattacharya et al., 2010; Chaurasia et al., 2012; Pandey et al., 2002, 2007; Sawidis et al., 2011). However, the As contamination occurred at elevated levels in the environment of Ambagarh tehsil, Rajnandgaon district, Chhattisgarh over $3000 \mathrm{~km}^{-2}$ (Pandey et al., 2007; Sawidis et al., 2011). Arsenic in this area is causing serious health hazards in humans by entering through water and food (Pandey et al., 2007). Hence, in this work, the contamination of water, soil, plant leaf and animal stool with As and other HMs i.e. Cr, Mn, $\mathrm{Cu}, \mathrm{Zn}$ and $\mathrm{Pb}$ in the contaminated village is described.

\section{METHODS/EXPERIMENTAL}

\subsection{Study area and sampling}

The study area is the Koudikasa village, Ambagarh Chowki, Rajnandgaon, CG, India $\left(20.78209^{\circ} \mathrm{N}\right.$ $80.74117^{\circ} \mathrm{E}$ ) where there are 10,000 humans and domestic animals i.e. cow, buffalo, goat and sheep. The trees and animal stool were reported as bioindicators to know environmental contaminations of the metals (Gupta, 2013; Sawidis et al., 2011). The water samples were collected from 5 locations i.e. tank and canal, hand pump and agricultural field (0$10 \mathrm{~cm}$ ) of the Kourikasa village in February, 2017 by using established methodologies. The leaves of forty five plants were collected manually. They were washed with deionized water and dried in the sunlight. The solid samples were died, crushed and sieved out particles of $<0.1 \mathrm{~mm}$.

\subsection{Analysis}

The physical characteristics (i.e. $\mathrm{pH}$, conductivity and TDS) of the water was measured at the spot. A $0.25 \mathrm{~g}$ of the solid sample was digested with acids $(3 \mathrm{~mL} \mathrm{HCl}$ and $1 \mathrm{~mL} \mathrm{HNO}_{3}$ ) in closed system with P/TMARS CEM (Varian Company) microwave oven. The acid extract was used for monitoring the metals with the GF-AAS and ICP-AES. The speciation of arsenic was quantified by the AFS technique.

\section{RESULTS AND DISCUSSION}

\subsection{Physicochemical characteristics}

The surface water (i.e. tank, reservoir and canal) and groundwater $(\mathrm{GW})$ were used for drinking purposes by the animals i.e. cow, buffalo, goat, sheep, etc. The concentrations of $\mathrm{As}, \mathrm{Cr}, \mathrm{Mn}, \mathrm{Cu}, \mathrm{Zn}$ and $\mathrm{Pb}$ in the GW $(\mathrm{n}=5)$ was ranged from $0.030-0.048$, $0.019-0.061,0.089-0.152,0.027-0.040,0.07-0.11$ and $0.005-0.015 \mu \mathrm{g} \mathrm{L}^{-1}$ with men value $(\mathrm{p}=0.05)$ of $0.038 \pm 0.06, \quad 0.120 \pm 0.021, \quad 0.032 \pm 0.005$, $0.096 \pm 0.015$ and $0.009 \pm 0.003 \mu \mathrm{gL}^{-1}$, respectively. The higher concentration of As and other HMs in the GW was observed, may be due to their mineralization from the bed rocks. Several folds higher concentration of As in the water was observed than prescribed value of $10 \mu \mathrm{g} \mathrm{L}^{-1}$. The higher As concentration in the water of the studied area than other regions of the country was found (Chaurasia et al., 2012).

The concentration of $\mathrm{As}, \mathrm{Cr}, \mathrm{Mn}, \mathrm{Cu}, \mathrm{Zn}$ and $\mathrm{Pb}$ $(\mathrm{n}=5)$ in the soils was ranged from 58-302, 45-73, 778-986, 64-105, 76-114 and 17-41 $\mathrm{mg} \mathrm{kg}^{-1}$ with mean value $(\mathrm{p}=0.05)$ of $207 \pm 97,60 \pm 10,893 \pm 72$, $84 \pm 15,94 \pm 13$ and $30 \pm 8 \mathrm{mg} \mathrm{kg}^{-1}$, respectively. The concentration of As in the soil was several folds higher than the background levels of $5.0 \mathrm{mg} \mathrm{kg}^{-1}$. 
The remarkably high As concentration in the soil of the studied area was marked.

The concentrations of the elements i.e. As, $\mathrm{Cr}, \mathrm{Mn}$, $\mathrm{Cu}, \mathrm{Zn}$ and $\mathrm{Pb}$ in 45 dried leaves were ranged from $0.3-27,3.3-25,18-159,9.1-62,29-238$ and $0.8-$ $8.0 \mathrm{mg} \mathrm{kg}^{-1}$ with mean value $(\mathrm{p}=0.05)$ of $5.6 \pm 1.4$, $11 \pm 2,89 \pm 10,27 \pm 4,86 \pm 12$ and $3.7 \pm 0.6 \mathrm{mg}$ $\mathrm{kg}^{-1}$, respectively. All leaves were contaminated with As at $56 \pm 14$ times higher than the permissible limit of $0.1 \mathrm{mg} \mathrm{kg}^{-1}$ (FAO/WHO, 2011). Similarly, all leaves were loaded with the $\mathrm{Zn}, \mathrm{Cr}$ and $\mathrm{Pb}$ at least $4 \pm 1,6 \pm 2$ and $17 \pm 4$ times higher than permissible limit of 20 , 2.3 and $0.3 \mathrm{mg} \mathrm{kg}^{-1}$, respectively. The higher concentration of As in the plant leaves of the studied area than values reported in other regions of the country and the world was observed (Bhattacharya et al., 2010; Pandey et al., 2002, 2007; Sawidis et al., 2011).

\subsection{Speciation}

In general, inorganic forms of As are more toxic in the environment than organic forms and, among inorganic forms, arsenite is more toxic than arsenate. In the soil samples, all As was in the inorganic forms: As(III) and $\mathrm{As}(\mathrm{V})$. In the stool samples, lower concentrations of the non-toxic, DMA (3.5\%) and MMA (1\%) were detected.

\subsection{Correlation and sources}

The correlation coefficient $\left(\mathrm{r}^{2}\right)$ of the elements i.e. As, $\mathrm{Cr}, \mathrm{Mn}, \mathrm{Cu}, \mathrm{Zn}$ and $\mathrm{Pb}$ among their mean concentrations in the SW, GW, soil and leaf samples was computed. They had good correlation $\left(\mathrm{r}^{2}=>0.91\right)$ among themselves except $\mathrm{Zn}$ which showed partial correlations, indicating origin from the similar sources i.e. arsenopyrite leaching, etc.

Some species i.e. D. bulbifera, A. concinna, $T$. foenumgraecum, L. purpureus, M. oleifera, T. grandis, H. sabdariffa, A. esculentus and A. marmelos, are seemed to be as $\mathrm{Zn}$ hyper accumulator species as the ratio of $\left[\mathrm{Zn}_{\text {leaf }}\right] /\left[\mathrm{Zn}_{\text {soil }}\right]$ was found $>1.0$. Similarly, the highest accumulation of other elements i.e. As, $\mathrm{Cr}, \mathrm{Mn}, \mathrm{Cu}$ and $\mathrm{Pb}$ was marked with leaf of plants i.e. Vigna unguiculata, Diospyros melanoxylon, Mangifera indica, Hibiscus sabdariffa and Zingiber officinale, respectively which could be assessed as bioindicators for the respective elements.

\subsection{Toxicity}

The concentrations of $\mathrm{As}, \mathrm{Cr}, \mathrm{Mn}, \mathrm{Cu}, \mathrm{Zn}$ and $\mathrm{Pb}$ were ranged from 41-60, 33-50, 212-301, 840-1220, 429630 and $39-84 \mathrm{mg} \mathrm{kg}^{-1}$ with mean value of $51 \pm 7$, $39 \pm 6,254 \pm 34,1003 \pm 120,529 \pm 71$ and $63 \pm 14$ $\mathrm{mg} \mathrm{kg}^{-1}$, respectively. The highest concentration of As was marked in the goat stool, may be due to high intake of the green leaves. The elements i.e. As, $\mathrm{Cr}, \mathrm{Mn}, \mathrm{Cu}$, $\mathrm{Zn}$ and $\mathrm{Pb}$ were enriched at least 9, 3, 3, 37, 6 and 17folds higher than the respective leaf value. The higher loading of three metals i.e. $\mathrm{Cu}, \mathrm{Zn}$ and $\mathrm{Pb}$ in the stool samples of the domestic animals than the soil sample was observed, may be due to preconcentration from the contaminated leaves. The skin cancers and fibrosis in the cow and sheep are seen in the studied area.

\section{CONCLUSIONS}

The whole environment (i.e. water, soil and plant) of Koudikasa village are contaminated with arsenic at the tremendous high level. Arsenic existed mostly in the inorganic As(V) form. The plant leaves i.e. Vigna unguiculata, Dalbergia melanoxylon, Mangifera indica, Hibiscus sabdariffa, Moringa oleifera and Zingiber officinale were as bio-indicator for assessing pollution of metals i.e. As, $\mathrm{Cr}, \mathrm{Mn}, \mathrm{Cu}, \mathrm{Zn}$ and $\mathrm{Pb}$, respectively. The stool samples of the domestic animals were contaminated with As at extremely high levels $\left(>50 \mathrm{mg} \mathrm{kg}^{-1}\right)$. They are enriched from 3-37-folds higher in the stool sample with respect to the leaf mean value. The skin cancers are observed in the animals of the studied area.

\section{ACKNOWLEDGEMENTS}

The UGC, New Delhi is greatly acknowledged for awarding the BSR grant to KSP.

\section{REFERENCES}

Bhattacharya, P., Samal, A.C., Majumdar, J. \& Santra, S.C. 2010. Arsenic contamination in rice, wheat, pulses, and vegetables: a study in an arsenic affected area of west Bengal, India. Water Air Soil Pollut. 213(1-4): 3-13.

Chaurasia, N., Mishra, A. \& Pandey, S.K. 2012. Finger print of arsenic contaminated water in India - a review. $J$. Forensic Res. 3: 172.

FAO/WHO 2011. Food Standards programme Codex committee on contaminants in foods Food. $C F / 5 I N F / 1$, pp. $1-89$.

Gupta, V. 2013. Mammalian feces as bio-indicator of heavy metal contamination in Bikaner zoological garden, Rajasthan, India. Res. J. Animal, Veterinary and Fishery Sci. 1(5): 10-15.

Hong, Y.S., Song, K.H. \& Chung, J.Y. 2014. Health effects of chronic arsenic exposure. J. Prev. Med. Public Health. 47(5): 245-252.

Pandey P.K., Yadav S., Nair S. \& Bhui, A. 2002. Arsenic contamination of the environment: a new perspective from central-east India. Environ. Int. 28(4): 235-245.

Pandey P.K., Yadav, S. \& Pandey, M. 2007. Human arsenic poisoning issues in central-east Indian locations: biomarkers and biochemical monitoring. Int. J. Environ. Res. Publ. Health 4(1): 15-22.

Patel K.S., Shrivas K., Brandt R., Jakubowski, N., Corns, W. \& Hoffmann, P. 2005. Arsenic contamination in water, soil, sediment and rice of central India. Environ. Geochem. Health 27(2): 131-145.

Sawidis, T., Breuste, J., Mitrovic, M., Pavlovic, P. \& Tsigaridas, K. 2011. Trees as bioindicator of heavy metal pollution in three European cities. Environ. Pollut. 159(12): 3560-3570. 